\title{
Temperature-dependent expression of virulence genes in fish-pathogenic bacteria
}

\section{José A. Guijarro*, Desirée Cascales, Ana I. García-Torrico, Mario García-Domínguez and Jessica Méndez}

Área de Microbiología, Departamento de Biología Funcional, Facultad de Medicina, Instituto de Biotecnología de Asturias, Universidad de Oviedo, Oviedo, Spain

Virulence gene expression in pathogenic bacteria is modulated by environmental parameters. A key factor in this expression is temperature. Its effect on virulence gene expression in bacteria infecting warm-blooded hosts is well documented. Transcription of virulence genes in these bacteria is induced upon a shift from low environmental to a higher host temperature $\left(37^{\circ} \mathrm{C}\right)$. Interestingly, host temperatures usually correspond to the optimum for growth of these pathogenic bacteria. On the contrary, in ectothermic hosts such as fish, molluscs, and amphibians, infection processes generally occur at a temperature lower than that for the optimal growth of the bacteria. Therefore, regulation of virulence gene expression in response to temperature shift has to be modulated in a different way to that which is found in bacteria infecting warm-blooded hosts. The current understanding of virulence gene expression and its regulation in response to temperature in fish-pathogenic bacteria is limited, but constant extension of our knowledge base is essential to enable a rational approach to the problem of the bacterial fish diseases affecting the aquaculture industry. This is an interesting issue and progress needs to be made in order to diminish the economic losses caused by these diseases. The intention of this review is, for the first time, to compile the scattered results existing in the field in order to lay the groundwork for future research. This article is an overview of those relevant virulence genes that are expressed at temperatures lower than that for optimal bacterial growth in different fish-pathogenic bacteria as well as the principal mechanisms that could be involved in their regulation.

\section{Keywords: temperature, gene regulation, fish pathogen, bacterial virulence, aquaculture}

\section{Introduction}

Bacteria are constantly subjected to different environmental influences, mainly related to their particular niche or lifestyle. One of the relevant factors influencing bacterial processes is temperature. Bacteria have to adapt their physiology to changes in temperature by adjusting their activities accordingly. Temperature accommodation is not only an acceleration-deceleration modulation of the whole cell's enzymatic activity but also affects membrane-associated functions and leads to changes in bacterial gene expression (Schumann, 2012). In many cases, these changes are caused even by small temperature changes. Thus, bacteria have developed precise and defined regulation systems to modulate the expression of specific genes in response to 
moderate temperature shifts (Eriksson et al., 2002; Shivaji et al., 2010; Steinmann and Dersch, 2013). In addition, bacteria also have response mechanisms to drastic changes in temperature. The paradigms of this adaptation are the cold and heat shock response systems under which the bacteria induce a fast response to sudden and extreme temperature shift (Guisbert et al., 2008; Shamovsky and Nudler, 2008; Barria et al., 2013). In any case, temperature variations involve remodeling gene expression through different temperature sensor systems that recognize this environmental alteration and trigger an adequate response (Shivaji et al., 2010; Steinmann and Dersch, 2013).

In particular, temperature adaptation is essential during the infection process of endothermic organisms by pathogenic bacteria. These bacteria have to adjust their physiology to the host temperature, which is usually higher than that encountered within a vector or in the natural environment. This accommodation may involve the induction of both virulence and metabolic genes (Konkel and Tilly, 2000). Different systems govern the induction of virulence gene expression by temperature in planktonic mammal-pathogenic bacteria such as those belonging to Yersinia, Salmonella, Shigella, Escherichia, Vibrio, and Listeria genera. The presence in the bacteria of virulence factors is unnecessary during the planktonic state but essential for the infection process. Switching between environmental and host niches is sensed by the cell as a group of variations in different parameters including temperature. In this way, bacteria save energy by not expressing virulence genes until they sense they have entered the host environment.

While molecular mechanisms governing the expression of virulence factors in relation to temperature in bacteria pathogenic to mammals, and particularly to humans, have been studied in detail (see excellent review, Konkel and Tilly, 2000; Johansson and Cossart, 2003; Steinmann and Dersch, 2013), little is known about the temperature-regulated virulence factors in fishassociated bacterial pathogens and even less about the systems involved in their regulation.

Disease development in fish is a complex process involving the interaction of a susceptible host, a virulent microorganism, and environmental factors. It is clear that in the aquaculture industry the third requirement is particularly important since the high densities and stress to which fish are commonly subjected favor the appearance of diseases that are infrequent or even non-existent in natural environments (Figure 1). A key environmental stress factor in outbreaks of most fish bacterial diseases in fish farms is water temperature. In some cases, outbreaks occur when water temperature drops to a certain value: Cold water vibriosis, (Enger et al., 1991); Cold water disease (Cipriano and Holt, 2005); Redmouth disease (Fernandez et al., 2007a). In others, such as: Lactococcosis (Vendrell et al., 2006), Haemorrhagic septicaemia (Austin and Austin, 2007), and Edwardsiellosis (Mohanty and Sahoo, 2007) outbreaks are related to an increase in water temperature. Interestingly, a remarkable number of bacterial diseases in aquaculture, particularly those of freshwater, occurred at temperatures below that of the optimal growth (TBO) of the infecting bacteria considering the optimum growth temperature for a particular bacterium to be that at which the fastest growth rate was observed under laboratory

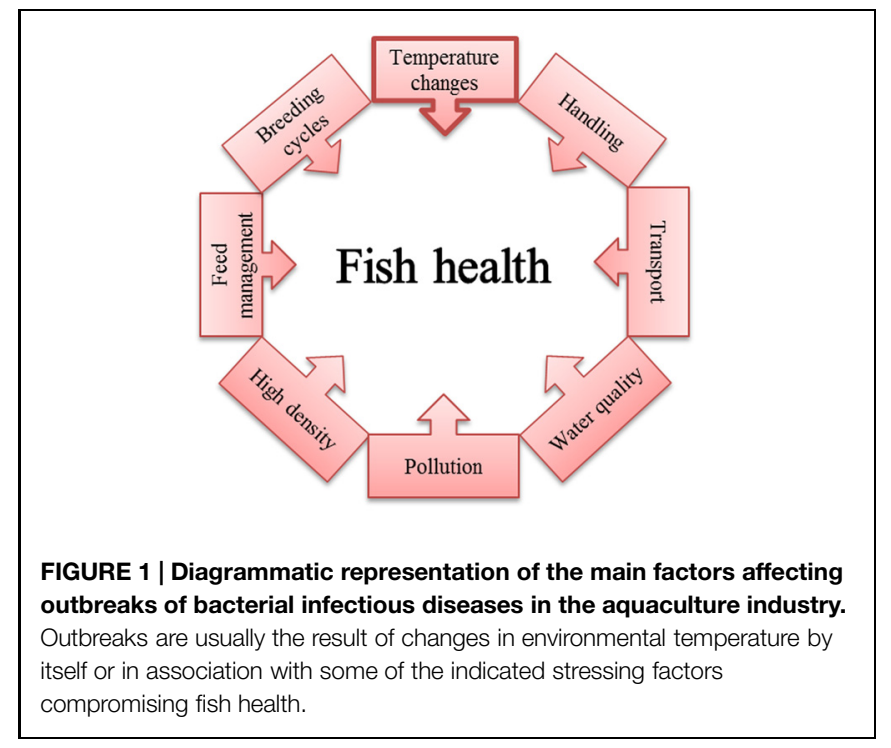

conditions. This temperature is usually higher than those found in the aquatic environment where the bacteria live or within their ectothermic hosts. Therefore, virulence gene expression in these bacteria should be regulated in such a way that maximum expression must occur at TBO. Nevertheless, since the body temperature of ectothermic animals is very close to the environmental temperature, additional factors must be necessary for full virulence, such as a co-regulation interaction between temperature and host metabolic processes.

\section{Sensing Temperature Changes in Mammal-Pathogenic Bacteria}

Different molecular mechanisms are involved in sensing temperature changes in mammal-pathogenic bacteria (Konkel and Tilly, 2000; Johansson and Cossart, 2003; Han et al., 2013; Steinmann and Dersch, 2013). Most of them are related to changes in DNA, RNA or protein conformation and alteration in membrane structure (rigidification) which determines in some cases the activation of a two-component signal transduction pathway (Steinmann and Dersch, 2013). It should be pointed out that some of these thermo-sensing systems could not work in fish-pathogenic bacteria. One example is the H-NS-mediated repression of virulence gene expression by binding to AT-DNA regions at low temperature. In this case, induction of virulence genes depends on an increase in temperature, corresponding to the entry into the host $\left(37^{\circ} \mathrm{C}\right)$, which causes $\mathrm{H}-\mathrm{NS}$ protein to be released from the AT-DNA regions, thus derepressing transcription and also enabling binding of transcriptional activators and so allowing expression of the regulated genes (Dorman, 1996; Hurme and Rhen, 1998; White-Ziegler and Davis, 2009). The H-NS protein is a universal regulator of the bacterial genome, particularly relevant in Enterobacteriaceae. Examples of its action are the regulation of the $\operatorname{virF}, s s r B$, and $y m o A$ genes, involved in the virulence of Shigella flexneri (Falconi et al., 1998), Salmonella enterica (Fass and Groisman, 
2009), and Yersinia species (Bohme et al., 2012), respectively. In fish-pathogenic bacteria, it is difficult to imagine how this system could work, since the temperature encountered by bacteria within the host is generally lower than their optimum growth temperature, this being the opposite of what happens in mammal-pathogenic bacteria.

RNA thermometers modulate translation efficiency of a particular mRNA in relation to temperature (Eriksson et al., 2002; Johansson and Cossart, 2003; Kortmann and Narberhaus, 2012; Han et al., 2013; Steinmann and Dersch, 2013; GrossoBecerra et al., 2014; Weber et al., 2014). They are sequences able to form intramolecular stem-loop structures affecting the ribosomal binding site (RBS) and the translation initiation codon. In that way, at low temperature, the mRNA conformation makes the RBS site inaccessible to the ribosome. When temperature increases and, in particular, at host temperature $\left(37^{\circ} \mathrm{C}\right)$, there is a stem-loop melting with a conformational change at the mRNA 5 'end, rendering the RBS accessible to the ribosome and making mRNA translation possible. This system depends on the high stability at low temperatures of mRNA 5'sequences involved in sequestering RBS. Therefore, it seems that this mechanism would not be appropriate for regulating virulence gene expression at TBO in fish-pathogenic bacteria. However, an RNA thermoswitch has already proved to be involved in gene regulation at $\mathrm{TBO}$ and it could be a system implicated in the regulation of virulence genes in fish-pathogenic bacteria. Thus, at optimal bacterial growth temperatures, the RNA forms stem-loops sequestering $\mathrm{RBS}$ and preventing virulence gene expression, whereas at TBO, RNA conformation changes, resulting in an accessible RBS and the initiation of translation (Kortmann and Narberhaus, 2012; Steinmann and Dersch, 2013). An example of this kind of regulation system is the $\operatorname{csp} A$ gene of Escherichia coli involved in the cold shock response (Yamanaka et al., 1999; Giuliodori et al., 2010). Indeed, $\operatorname{csp} A$ mRNA undergoes a structural rearrangement at low temperature in relation to the conformation at $37^{\circ} \mathrm{C}$, resulting in more efficient translation.
At $37^{\circ} \mathrm{C}$ the $5^{\prime}$ end of the transcribed $\operatorname{csp} A$ mRNA forms a secondary structure in which RBS is occluded, whereas at $10^{\circ} \mathrm{C}$, an entirely new secondary structure is formed, leaving the RBS sequence accessible to the ribosome (Giuliodori et al., 2010; Figure 2).

In addition, regulation by trans-acting non-coding RNAs, which has been studied in other pathogens, might be an interesting area to explore in fish-pathogenic bacteria. This basically involves the temperature regulation of $r p o S$ expression, a general stress response sigma factor in bacteria. The effects of RpoS on pathogenesis are highly variable and depend on the species (Dong and Schelhorn, 2010). Nevertheless, it is well established that induction of RpoS by small non-coding RNAs is enhanced during growth at low temperatures (Rapoila and Gottesman, 2001; Rapoila et al., 2003; Lybecker and Samuels, 2007). This process is dependent on the presence of the sRNA DsrA (Kortmann and Narberhaus, 2012; Han et al., 2013). Expression of DsrA is enhanced at low temperature, resulting in base pairing with rpoS mRNA in the $5^{\prime}$ non-co ding region, bringing about an increase in rpoS translation (Rapoila and Gottesman, 2001; Rapoila et al., 2003; McCullen et al., 2010). Thus an RpoS-like system could be one of the mechanisms able to activate virulence factors in fish-pathogenic bacteria at TBO.

Temperature-dependent gene expression could also be mediated by means of proteins. Amongst the different regulation mechanisms in which proteins are involved, those based on repressing promoter activity at TBO by protein DNA binding and further protein-DNA disassembling at host temperatures $\left(37^{\circ} \mathrm{C}\right)$ deserve special attention. Examples of this kind of regulation are the TlpA and HtrA proteins of S. enterica (Gal-Mor et al., 2006) and in Helicobacter pylori (Hoy et al., 2012), respectively, both involved in the virulence of these bacteria. These regulation systems are of interest, but, may not participate in virulence gene modulation in fish-pathogenic bacteria. However, it is important to consider two other mechanisms that could well be involved
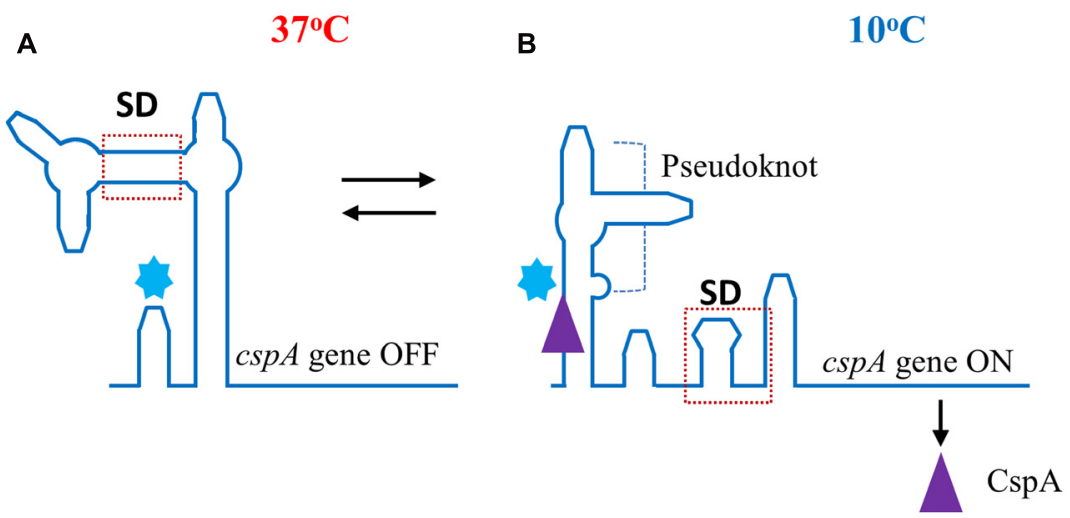

FIGURE 2| Transcription of the gene encoding the cold shock protein CspA depends on an mRNA rearrangement at low temperature. (A) Interaction of the $5^{\prime}$ untranslated region and the coding region blocks the Shine-Dalgarno (SD) sequence and represses translation of $\operatorname{csp} A$ mRNA at $37^{\circ} \mathrm{C}$. (B) $\mathrm{A}$ cold shock $\left(10^{\circ} \mathrm{C}\right)$ produces the liberation of the $\mathrm{SD}$ sequence which allows expression of $\operatorname{csp} A$ gene. Conformation of the mRNA at $10^{\circ} \mathrm{C}$ is stabilized by pseudoknot formation. This is further abolished after binding of $\operatorname{CspA}(\boldsymbol{\Delta})$ to the cold box (n) in the late phase of cold shock adaption. 
in virulence gene regulation at TBO: protein conformational changes that abolish DNA-binding at host temperature $\left(37^{\circ} \mathrm{C}\right)$, stopping gene transcription, i.e., the RovA system in Yersinia species (Ellison et al., 2004; Marceau, 2005; Cathelyn et al., 2006); and the repressor/antirepressor complex MogR:GmaR regulating motility of Listeria monocytogenes (Kamp and Higgins, 2011). In both cases, gene expression takes place at TBO and it is impaired at host temperature $\left(37^{\circ} \mathrm{C}\right)$. In Yersinia enterocolitica, RovA binds at $25^{\circ} \mathrm{C}$ at the $5^{\prime}$ end of the inv gene, activating its transcription to produce invasin, a protein involved in the first steps of tissue colonization (Ellison et al., 2004; Figure 3). At $37^{\circ} \mathrm{C}$ a conformational RovA change prevents its binding to DNA and makes it susceptible to degradation by the Lon protease (Herbst et al., 2009), impeding gene expression (Cathelyn et al., 2006; Ellison and Miller, 2006; Figure 3). As in Yersinia, the first steps of the infection process in L. monocytogenes imply the activation of genes at temperatures below $30^{\circ} \mathrm{C}$. In particular, genes related to motility are needed for bacterial entry into the host cells (O’Neil and Marquis, 2006). This flagelar motility (flaA gene) is temperature-regulated through the GmaR:MogR complex, which once bound to the upstream promoter region, enables flaA gene expression of L. monocytogenes at $30^{\circ} \mathrm{C}$ (Kamp and Higgins, 2011). Conformational changes in $\mathrm{GmaR}$ at $37^{\circ} \mathrm{C}$ prevent its union to $\operatorname{MogR}$, which is thus able to act as a repressor of the fla $\mathrm{A}$ gene by itself (Shen and Higgins, 2006), blocking its expression and rendering the bacterial cells non-motile just after invasion has occurred.

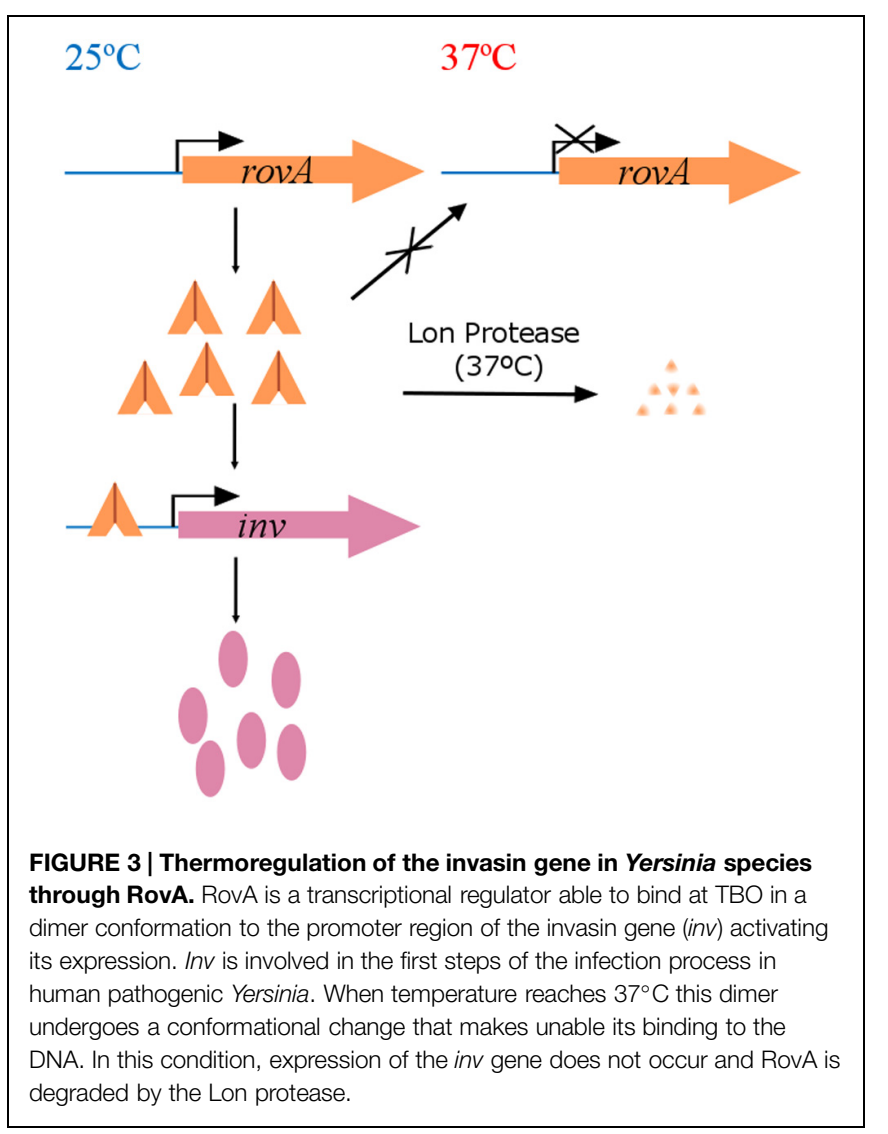

\section{Sensing Temperature Changes in Plant-Pathogenic Bacteria}

Thermoregulated expression of virulence factors in plantassociated bacteria was first summarized by Smirnova et al. (2001). So far, two-component systems are the only ones described as thermosensing mechanisms related to virulence gene expression at TBO in plant-pathogenic bacteria. Agrobacterium tumefaciens VirAG (Jin et al., 1993) and Pseudomonas syringae CorSR are both involved in tumor formation and virulence-enhancing phytotoxin production, respectively. In A. tumefaciens, the etiological agent of "Crown Gall disease" in plants, low temperatures play a relevant role in the induction of virulence gene expression. This induction is in part due to the VirAG two-component regulatory system in which VirA undergoes a reversible conformational change at temperatures greater than $32^{\circ} \mathrm{C}$ that inactivates the sensor kinase (Melchers et al., 1989; Jin et al., 1993). So, VirA constitutes a thermosensor related to the progression of the infection processes at temperatures below $32^{\circ} \mathrm{C}$. In the same way, the bacterial blight pathogen $P$. syringae produces the phytotoxin coronatine in a temperature-dependent manner (Palmer and Bender, 1993; Ullrich et al., 1995; Arvizu-Gómez et al., 2013). The regulatory mechanism involved in the synthesis of this toxin is the CorRS two-component system in which the histidine kinase autophosphorylation of the histidine kinase CorS is abolished at $28^{\circ} \mathrm{C}$, whereas at $18^{\circ} \mathrm{C}$ this membrane protein has the phosphorylation domain accessible (Palmer and Bender, 1993; Ullrich et al., 1995; Arvizu-Gómez et al., 2013). Therefore, at the appropriate temperature $\left(18^{\circ} \mathrm{C}\right)$, CorS phosphorylation triggers the expression of the biosynthetic operons encoding coronatine.

\section{Temperature-Dependent Virulence Gene Expression in Fish-Pathogenic Bacteria}

Different fish-pathogenic bacteria produce diseases in their host in response to $\mathrm{TBO}$, which seems to be a key element for these bacteria to produce virulence factors. This is not exclusive to fish pathogens but also true for infection in plants (Smirnova et al., 2001), and probably in molluscs (Romalde et al., 2014). Depending on the niche of these bacteria, an additional characteristic should be considered in gene temperature regulation. In fact, the environmental temperature encountered by these bacteria is, in many cases, similar to that found in the ectothermic host. Therefore, it may be deduced that in order to prevent energy waste it is probable that additional factors, other than temperature, must be frequently involved in virulence gene regulation during host invasion and colonization. Otherwise, virulence genes in these bacteria would be on in the planktonic state at environmental temperature.

As described above, some of the systems regulating temperature-dependent virulence factor expression in bacteria pathogenic to mammals could not function in fish- pathogenic bacteria because a large number of these pathogens induce virulence factors at $\mathrm{TBO}$. 
Different approaches have been undertaken in order to identify up-regulated virulence genes at TBO in fish-pathogen bacteria.

\section{Identification of Virulence Genes Induced at TBO}

\section{Yersinia ruckeri}

In vivo expression technology (IVET) was used for the selection of specifically in vivo induced genes in Y. ruckeri, the etiological agent of the "Enteric red mouth disease" of salmonids, (Fernandez et al., 2004). Expression of some of the genes selected was found to be higher at $18^{\circ} \mathrm{C}$, the temperature at which outbreaks of disease occur, than at $28^{\circ} \mathrm{C}$, the optimal bacterial growth temperature. Thus, the expression of the traHIJKCLMN operon encoding a putative type IV secretion system involved in the virulence of the bacterium was reduced by $64 \%$ upon incubation at optimal growth temperature in relation to $18^{\circ} \mathrm{C}$ (Méndez et al., 2009; Table 1).

In the same way, the expression of two genes encoding extracellular proteins involved in bacterial virulence were also temperature regulated. The expression of YhlA haemolysin and Yrp1 protease was approximately seven and threefold higher at $18^{\circ} \mathrm{C}$ than at $28^{\circ} \mathrm{C}$, respectively (Fernandez et al., 2002, 2003, 2007b). In vivo expression of Yrp1 in rainbow trout

TABLE 1 | Virulence-related genes which are up-regulated at TBO in fish-pathogenic bacteria.

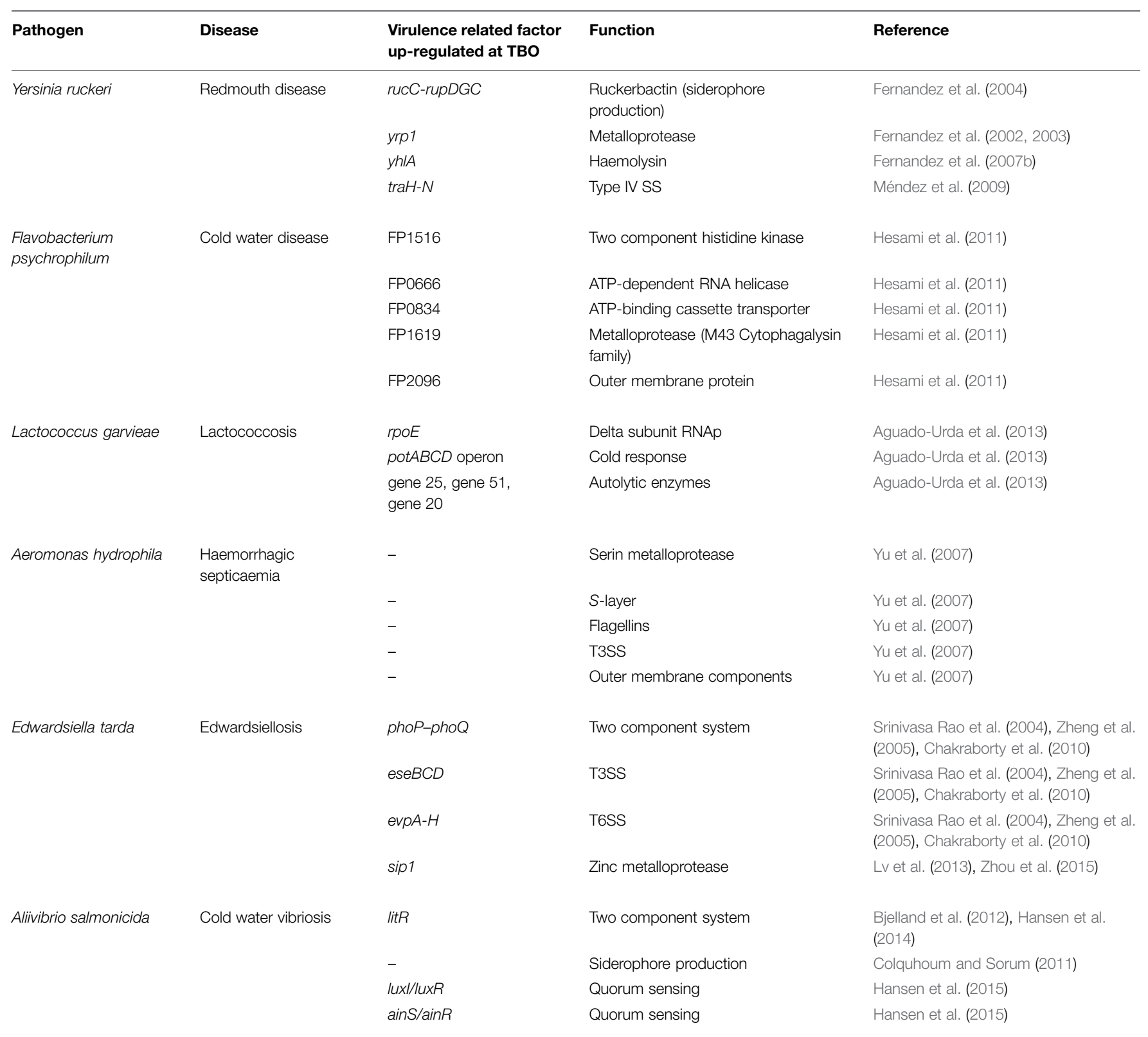


kept at $18^{\circ} \mathrm{C}$ was confirmed by using the lux operon as a reporter system (Méndez and Guijarro, 2013). Ruckerbactin, a cathecholate siderophore iron acquisition system was also regulated by temperature (Fernandez et al., 2004; Table 1). Therefore, the temperature-dependent modulation of virulence genes in Y. ruckeri tends to optimize the expression of these in conditions mimicking those encountered in the host. However, despite the important work carried out in the regulation of virulence genes in human pathogenic Yersinia species, there is no study related to how $Y$. ruckeri regulates virulence gene expression at TBO. It seems that some of the temperature sensing systems existing in human pathogenic Yersinia species such as $\mathrm{H}-\mathrm{NS}$ and conformational changes in the structure of the $5^{\prime}$ end in mRNA would be unlikely to work, at least in a similar way, in Y. ruckeri at TBO. However, RovA, RpoS as well as twocomponent systems could be relevant in the Y. ruckeri virulence expression at TBO.

\section{Flavobacterium psychrophilum}

The Gram-negative bacterium F. psychrophilum is the etiological agent of "Bacterial cold water disease", one of the major causes of economic losses in the salmonid aquaculture industry. The disease occurs at temperatures below $14^{\circ} \mathrm{C}, 20^{\circ} \mathrm{C}$ being the optimal growth temperature of the bacterium (Cipriano and Holt, 2005; Starliper, 2011). Therefore, it is clear that expression of virulence genes at $\mathrm{TBO}$ is a key element in the infection process. The first indication of this came from the studies related to the extracellular metalloproteases Fpp1 and Fpp2 (Secades et al., 2001; Pérez-Pascual et al., 2011; Gómez et al., 2012). Extracellular proteolytic activity was linked by different authors to the virulence of this bacterium due to its potential role in the degradation of host tissues (Bertolini et al., 1994; Ostland et al., 2000). Interestingly, Fpp1 and Fpp2 metalloproteases of F. psychrophilum are overproduced at $12^{\circ} \mathrm{C}$ in relation to $18^{\circ} \mathrm{C}$ (Secades et al., 2001; Gómez et al., 2012). This up-regulated gene expression at $12^{\circ} \mathrm{C}$ was confirmed by transcriptional fusion using $g f p$ as a reporter gene (Gómez et al., 2012).

TBO-regulated genes in this bacterium were identified by Hesami et al., (2011). Using suppression subtractive hybridization $(\mathrm{SSH})$ a set of genes that were up-regulated at $8^{\circ} \mathrm{C}$ versus $20^{\circ} \mathrm{C}$ were defined (Table 1). Among them should be highlighted a histidine kinase temperature sensor belonging to a twocomponent system. This sensor is similar to the LytS involved in the regulation of cell autolysis (Brunskill and Bayles, 1996) and biofilm formation in different bacteria (Sharma-Kuinkel et al., 2009), and whose expression increased about 18 -fold at $8^{\circ} \mathrm{C}$ versus $20^{\circ} \mathrm{C}$. Another gene that was identified encodes an ATPdependent RNA helicase, which is up-regulated approximately 11 -fold at $8^{\circ} \mathrm{C}$ and whose function could be to facilitate the initiation of transcription at low temperature by destabilizing the mRNA secondary structure (Schmid and Linder, 1992; Lim et al., 2000). In addition, this kind of enzyme has been involved in the regulation of bacterial virulence in $H$. pylori and Clostridium perfringens (Heung and Del Poeta, 2005). As was described above, extracellular proteolytic activity is related to pathogenesis. In particular, zinc-dependent metalloprotease activity was suggested to play an important role in muscle necrosis in rainbow trout with F. psychrophilum infection (Ostland et al., 2000). In the SSH study, the M43 cytophagalysin zinc-dependent metalloprotease gene was induced at $8^{\circ} \mathrm{C}$, suggesting its involvement in the infection process; DNA gyrase subunits $\mathrm{A}$ and $\mathrm{B}$ were also induced at $8^{\circ} \mathrm{C}$. GyrA had already been described as a coldinduced protein in bacteria (Scherer and Neuhaus, 2006) and its role seems to be related to the increase in DNA negative supercoiling at TBO. Additionally, an ABC transport system, an outer membrane protein antigen and a recombinase (recA), as well as four housekeeping genes were also up-regulated at $8^{\circ} \mathrm{C}$ (Hesami et al., 2011). All the SSH-identified genes were upregulated in 12 different strains of $F$. psychrophilum from different origins, indicating that the induction of these genes at TBO is a common process in the species.

\section{Lactococcus garvieae}

Lactococcus garvieae is a ubiquitous and widely distributed Gram-positive bacterium. It is the causative agent of the fish disease "Lactococcosis" (Vendrell et al., 2006), although it can also produce septicaemia in humans as an opportunistic pathogen (Russo et al., 2012). Lactococcosis is one of the most relevant diseases affecting farmed fish species, particularly rainbow trout (Oncorhynchus mykiss; Vendrell et al., 2006; Reimundo et al., 2011) and outbreaks occur at water temperatures around $18^{\circ} \mathrm{C}$. The bacterium has also been isolated from different animal sources, including cows, pigs, cats, and horses (AguadoUrda et al., 2010) and even from foods, meat and dairy products (Ferrario et al., 2012). The ability to grow in such different environments and to infect both endothermic and ectothermic animals, suggests the existence of changes in gene expression, and in particular, changes affecting virulence genes. The expression of these depends on the environmental signals encountered inside the host and so the temperature range over which L. garvieae expresses virulence factors could be really wide, varying from 18 to $37^{\circ} \mathrm{C}$.

An interesting study using transcriptome analysis was assessed in two L. garvieae strains isolated from fish and humans to investigate the effect of growth temperature $\left(18^{\circ} \mathrm{C}\right.$ vs. $\left.37^{\circ} \mathrm{C}\right)$ on differential gene expression (Aguado-Urda et al., 2013). Interestingly, in the fish-pathogenic strain, several genes linked to virulence were up-regulated at $18^{\circ} \mathrm{C}$ vs. $37^{\circ} \mathrm{C}$ (Table 1). This was the case of $r p o E$, encoding the delta subunit of RNA polymerase. In addition to its role in global regulation during environmental adaptation, this gene has been linked to virulence in Gram-positive and Gram-negative bacteria such as Streptococcus agalactiae (Jones et al., 2003; Seepersaud et al., 2006) and Vibrio harveyi (Rattanama et al., 2012), respectively. Three genes related to virulence in gram-positive bacteria and involved in autolysis have also been identified. The role of these genes in pathogenesis seems to be related to the release of membrane and wall compounds during bacteriolysis, which would act on macrophages and would induce an immune response resulting in septic shock (Ginsburg, 2002). Finally, other genes over-expressed at $18^{\circ} \mathrm{C}$ were those belonging to the cold response polyamine transport operon pot $A B C D$, which is similar to that involved in the pathogenesis of $S$. pneumoniae and 
necessary for survival of the bacteria in host environments (Ware et al., 2006).

\section{Aeromonas hydrophila}

Aeromonas hydrophila, a ubiquitous Gram-negative bacterium, is an opportunistic pathogen of different endothermic animals, including humans, as well as ectothermic hosts such as rainbow trout (Thune et al., 1993; Austin and Austin, 2007). It can grow at temperatures ranging from 4 to $42^{\circ} \mathrm{C}$ (Rouf and Rigney, 1971), although the capacity to grow at the extremes of this range varies among strains. Different studies have clearly established that TBO is an inductor of virulence gene expression in A. hydrophila. The composition of the extracellular proteome produced at 25 versus $37^{\circ} \mathrm{C}$ showed that the total amount of extracellular products was significantly lower at $37^{\circ} \mathrm{C}$ than that at $25^{\circ} \mathrm{C}$ in spite of the growth rate being greater at $37^{\circ} \mathrm{C}$ (Yu et al., 2007). A Maldi-Toff analysis of these extracellular products showed a higher production at $25^{\circ} \mathrm{C}$ of a serin-metalloprotease, S-layer and flagellins among others, than was seen at $37^{\circ} \mathrm{C}$ (Yu et al., 2007; Table 1). In the same way, proteins related to the type III secretion system were also up-regulated at $25^{\circ} \mathrm{C}$ (Yu et al., 2007). TBO also had an influence on the composition of outer membrane components and the virulence of this pathogen (Yu et al., 2007). In fact, cells grown at $20^{\circ} \mathrm{C}$ showed higher levels of some phospholipid and different LPS aspect in relation to those cultured at $37^{\circ} \mathrm{C}(\mathrm{Yu}$ et al., 2007). These results were further confirmed by the effect of the Wzz protein in the regulation of LPS chain length (Jimenez et al., 2008). The gene encoding Wzz showed a substantially greater level of expression at $20^{\circ} \mathrm{C}$ than that at $37^{\circ} \mathrm{C}$, which resulted in higher LPS production at TBO with effects on the virulence of $A$. hydrophila (Merino et al., 1992). All of this, together with the fact that strains grown at $20^{\circ} \mathrm{C}$ were more virulent for fish and also for mice, indicates that TBO plays an essential role in the control of $A$. hydrophila virulence.

\section{Thermosensing Systems Involved in Virulence}

\section{Edwardsiella tarda}

Edwardsiella tarda infects many species of farmed fish, causing "Edwardsiellosis," a haemorrhagic septicaemia that leads to important losses in aquaculture (Thune et al., 1993; Austin and Austin, 2007). This Gram-negative bacterium has a broad host range and also causes infections in higher animals, including humans, in which it causes gastrointestinal disorders (Plumb, 1993) and bacteraemia (Yang and Wang, 1999) amongst other pathologies (Osiri et al., 1997; Slaven et al., 2001). Although pathogenesis of E. tarda is multifactorial, the two-component system PhoP-PhoQ detects changes in environmental temperature (Chakraborty et al., 2010). Indeed, PhoQ is a histidine kinase which senses temperature changes through conformational modification in its secondary structures (Figure 4). As a result, autophosphorylation of PhoQ only takes places over a defined range of temperature around $30^{\circ} \mathrm{C}$ (Figure 4). This allows the transfer of the phosphate group from PhoQ to PhoP. When phosphorylated, PhoP binds to the

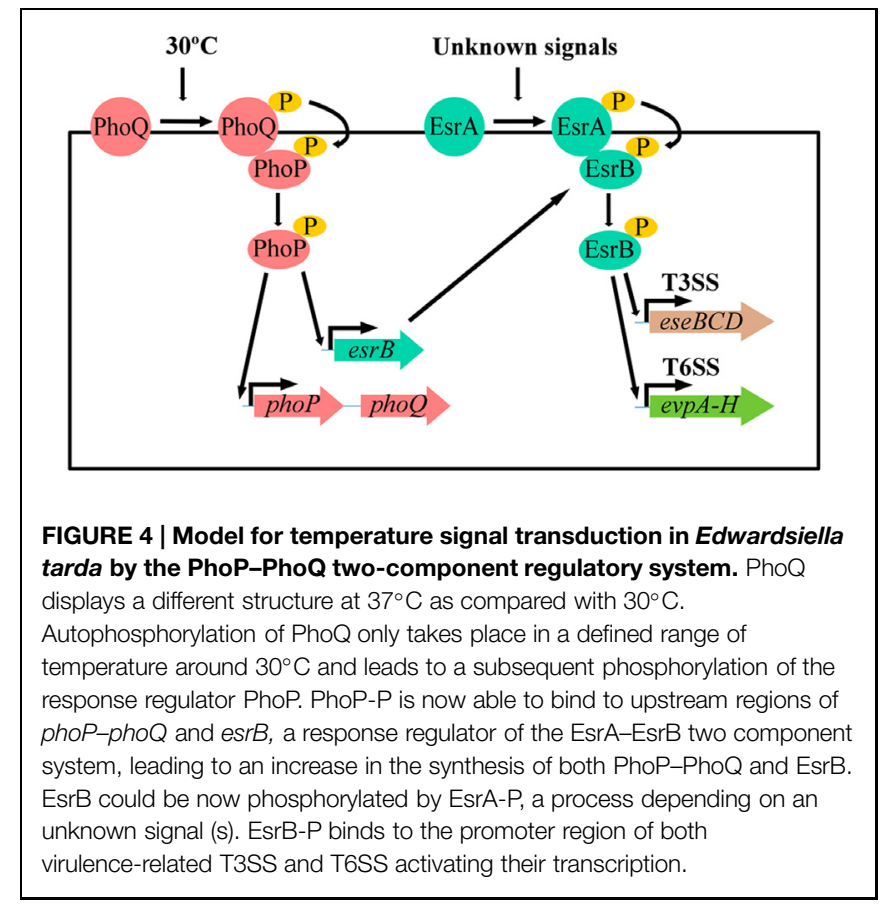

promoter region of esrB and activates its transcription (Figure 4). EsrB is a response regulator of another two-component system (EsrA-EsrB). Phosphorylated EsrB binds to the promoter region of at least two clusters of genes codifying type III (EseBCD) and type VI (EvpA-H) secretion systems, activating their transcription (Srinivasa Rao et al., 2004; Chakraborty et al., 2010; Figure 4). Both Type III and Type VI secretion systems are associated with virulence in this bacterium (Srinivasa Rao et al., 2003, 2004; Zheng et al., 2005; Wang et al., 2009). Interestingly, expression of these clusters together with esrB was temperature-dependent and was higher at $25^{\circ} \mathrm{C}$ than at $37^{\circ} \mathrm{C}$ (Srinivasa Rao et al., 2004). In the same way, expression of evpA and evpC was reduced by $84 \%$ at $37^{\circ} \mathrm{C}$ when compared with expression at $25^{\circ} \mathrm{C}$ (Srinivasa Rao et al., 2004). Therefore, these genes, essential for virulence in E. $\operatorname{tarda}$, were suppressed at $37^{\circ} \mathrm{C}$. Besides, a total of 13 proteins in E. tarda were found to require the presence of PhoP for full expression, specifically the zinc metalloprotease Sip1 (Lv et al., 2013). This was found to be essential for serum resistance and host infection (Zhou et al., 2015), corroborating once more the relation between TBO induction of PhoP and E. tarda virulence. Protein secretion was also significantly lowered at $37^{\circ} \mathrm{C}$ in E. tarda compared to $25^{\circ} \mathrm{C}$. In addition, in a challenge experiment, $90 \%$ of the fish injected with cells grown at $37^{\circ} \mathrm{C}$ survived, whereas $70 \%$ of the fish died when they received bacteria grown at $25^{\circ} \mathrm{C}$ (Srinivasa Rao et al., 2004). These results clearly established that the expression of these two protein secretion systems involved in the virulence of E. tarda was significantly lower at $37^{\circ} \mathrm{C}$ than at $25^{\circ} \mathrm{C}$ and depends on the PhoP-PhoQ system.

\section{Vibrio (Aliivibrio) salmonicida}

Vibrio salmonicida causes "Cold water vibriosis" in farmed salmonid fish, a systemic disease with hemorrhages and anemia as 
the main signs (Holm et al., 1985; Egidius et al., 1986). Outbreaks of the disease appear in seawater and generally at temperatures below $10^{\circ} \mathrm{C}$, although the species is able to grow until $20^{\circ} \mathrm{C}$ (Enger et al., 1991).

Quorum sensing is a well-defined cell-density-dependent regulation system in bacteria that is involved in the coordination of different activities related to pathogenesis. In $V$. salmonicida this quorum sensing system regulates biofilm formation through LitR (Bjelland et al., 2012; Hansen et al., 2014). Mutation of litR leads to greater adhesion, cell aggregation, biofilm formation, and higher motility in relation to the parental strain (Bjelland et al., 2012). Interestingly, the litR regulatory effects are under temperature regulation. At low temperature $\left(4-8^{\circ} \mathrm{C}\right)$ there were important differences in biofilm formation and colony morphology between parental and litR mutant strains. Nevertheless, at temperatures above $10-12^{\circ} \mathrm{C}$, the behavior of these strains was more similar to each other in relation to these phenotypes (Hansen et al., 2014). This shows that at temperatures close to that of the disease development, the negative regulatory effect of litR is weak or absent. Indeed, challenge experiments in Atlantic salmon using parental, litR mutant and litR complemented $V$. salmonicida strains showed a reduced mortality of the mutant in relation to the parental and complemented strains (Bjelland et al., 2012). All of this serves to indicate that temperature in $V$. salmonicida is a key factor involved in virulence regulation. Besides, LuxI/LuxR and AinS/AinR quorum sensing systems in A. salmonicida were recently shown to be dependent on growth temperature (Hansen et al., 2015). Indeed, $N$-acyl-homoserine lactones were efficiently produced by both systems when bacteria were grown at 6 or $12^{\circ} \mathrm{C}$, whereas at $16^{\circ} \mathrm{C}$ this production decreased to values less than $5 \%$ of the maximum concentration found at $6^{\circ} \mathrm{C}$ (Hansen et al., 2015). Interestingly, LitR was found to be a positive regulator of both luxI and ainS. Therefore, a new link was established between maximum expression of quorum sensing systems at low temperature and virulence.

This is also supported by the effect of temperature on siderophore production and the regulation of iron outer membrane proteins in this bacterium (Colquhoum and Sorum, 2011). Hydroxamate siderophore was produced only at $10^{\circ} \mathrm{C}$ or less, and in the same way iron-regulated membrane proteins were suppressed at $15^{\circ} \mathrm{C}$ compared to the expression at $10^{\circ} \mathrm{C}$ or less (Colquhoum and Sorum, 2011; Table 1). Since iron chelator

\section{References}

Aguado-Urda, M., Cutuli, M. T., Blanco, M. M., Aspiroz, C., Tejedor, J. L., Fernández-Garayzábal, J. F., et al. (2010). Utilization of lactose and presence of the phospho- $\beta$-galactosidase (lacG) gene in Lactococcus garvieae isolates from different sources. Int. Microbiol. 13, 189-193. doi: 10.2436/20.1501.01.125

Aguado-Urda, M., Gibello, A., Blanco, M. M., Fernandez-Garayzabal, J. F., LópezAlonso, V., and López-Campos, G. H. (2013). Global transcriptome analysis of Lactococcus garvieae strains in response to temperature. PLoS ONE 8:e79692. doi: 10.1371/journal.pone.0079692

Arvizu-Gómez, J. L., Hernández-Morales, A., Pacheco Aguilar, J. R., and AlvarezMorales, A. (2013). Transcriptional profile of Pseudomonas syringae pv. phaseolicola NPS3121 at low temperature: physiology of phytopathogenic bacteria. BMC Microbiol. 13:81. doi: 10.1186/1471-2180-13.81 systems are usually virulence factors, it could be deduced that $\mathrm{TBO}$ is involved in the control of pathogenicity of this bacterium.

\section{Conclusion and Perspectives}

From these limited studies that form the baseline to initiate further approaches in the field, it seems that extracellular enzymes, iron sequestering systems, bacteriolysis-related proteins, as well as secretion systems are some of the virulence factors which are up-regulated at TBO in fish-pathogenic bacteria. Two temperature-dependent regulatory systems have been described in fish pathogens: a two-component regulatory system in E. tarda working in a similar way to the ones described in mammals and plant pathogenic bacteria, and the $l i t R$, a negative regulator of $V$. salmonicida involved in blocking virulence-related genes expression.

A priori, only some of the existing regulatory systems in human pathogenic bacteria could be functional in fishpathogenic bacteria (i.e., RovS, RpoS-like systems and different kinds of RNA thermometers). It is more than likely that new virulence regulation mechanisms are still to be discovered in this kind of bacteria. It is particularly noteworthy that in many cases there are no differences between the environmental and the host temperature. Therefore, if virulence genes in fish-pathogenic bacteria are induced exclusively under TBO, they should be active in the planktonic state. It is tempting to speculate that bacteria could have additional intertwined systems regulating the expression of virulence factors specifically in the animal through the recognition of other environmental signals encountered inside the host.

Therefore, more studies are needed to determine the molecular mechanisms underlying the regulation of virulence gene expression in response to temperature in these bacteria in order to address rational strategies to deal with bacterial diseases in the aquaculture industry.

\section{Acknowledgments}

The work in the author's laboratory is supported by grants AGL2009-07003 and AGL2012-35808, from the Ministry of Economy and Competitiveness (MINECO) of Spain.

Austin, B., and Austin, D. A. (2007). "Bacterial fish pathogens," in Diseases of Farmed and Wild Fish, 4th Edn, ed. P. Dobbins (Chichester: Praxis Publishing Ltd), 81.

Barria, C., Malecki, M., and Arraiano, C. M. (2013). Bacterial adaptation to cold. Microbiology 159, 2437-2443. doi: 10.1099/mic.0. 052209-0

Bertolini, J. M., Wakabayashi, H., Watral, V. G., Whipple, M. J., and Rohovec, J. S. (1994). Electrophoretic detection of protease from selected strains of Flexibacter psychrophilus and assessment of their variability, J. Aquat. Anim. Health 6, 224-233. doi: 10.1577/1548-8667(1994)006

Bjelland, A. M., Sørum, H., Tegegne, D. A., Winther-Larsen, H. C., Willassen, N. P., and Hansen, H. (2012). LitR of Vibrio salmonicida is a salinity-sensitive quorum-sensing regulator of phenotypes involved in host interactions and virulence. Infect. Immun. 80, 1681-1689. doi: 10.1128/IAI.06038-11 
Bohme, K., Streinmann, R., Kortmann, J., Seekircher, S., Heroven, A. K., Berger, E., et al. (2012). Concerted actions of a thermo-labile regulator and a unique intergeneic RNA thermosensor control Yersinia virulence. PLoS Pathog. 8:e1002518. doi: 10.1371/journal.ppat.1002518

Brunskill, E. W., and Bayles, K. W. (1996). Identification of LytSR-regulated genes from Staphylococcus aureus. J. Bacteriol. 178, 5810-5812. doi: 10.1128/JB.00 348-09

Cathelyn, J. S., Crosby, S. D., Lathem, W. W., Golldman, W. E., and Miller, V. L. (2006). RovA, a global regulator of Yersinia pestis, specifically required for bubonic plague. Proc. Natl. Acad. Sci. U.S.A. 103, 13514-13519. doi: 10.1073/pnas.0603456103

Chakraborty, S., Li, M., Chatterjee, C., Sivaraman, J., Leung, K. Y., and Mok, Y.-K. (2010). Temperature and $\mathrm{Mg}^{2+}$ sensing by a Novel PhoP-PhoQ two-component system for regulation of virulence in Edwardsiella tarda. J. Biol. Chem. 285, 38876-38888. doi: 10.1074/jbcM110. 179150

Cipriano, R. C., and Holt, R. A. (2005). "Flavobacterium psychrophilum, cause of bacterial cold water disease and rainbow trout fry syndrome," in Fish Disease Leaflet No. 86. United States Department of the Interior U.S. Geological Service, Kearneysville, WV: National Fish Health Research Laboratory.

Colquhoum, D. J., and Sorum, H. (2011). Temperature dependent siderophore production in Vibrio salmonicida. Microb. Pathog. 31, 213-219. doi: 10.1006/mpat.2001.0464

Dong, T., and Schelhorn, H. E. (2010). Role of RpoS in virulence of pathogens. Infect. Immun. 78, 887-897. doi: 10.1128/IAI.00882-09

Dorman, C. J. (1996). Flexible response: DNA supercoiling, transcription and bacterial adaptation to environmental stress. Trends Microbiol. 4, 214-216. doi: 10.1016/0966-842X(96)30015-2

Egidius, E., Wiik, R., Andersen, K., Hoff, K. A., and Jjeltnes, B. (1986). Vibrio salmonicida sp. Nov., a new fish pathogen. Int. J. Syst. Bacteriol. 36, 518-520. doi: 10.1099/00207713-36-4-518

Ellison, D. W., Lawrenz, M. B., and Miller, V. L. (2004). Invasin and beyond: regulation of Yersinia virulence by RovA. Trends Microbiol. 12, 296-300. doi: 10.1016/j.tim. 2004.04.006

Ellison, D. W., and Miller, V. L. (2006). Regulation of virulence by members of the MarR/SlyA family. Curr. Opin. Microbiol. 9, 153-159. doi: 10.1016/j.mib.2006.02.003

Enger, O., Husevag, B., and Goksoyr, J. (1991). Seasonal variation in presence of Vibrio salmonicida and total bacterial counts in Norwegian fish- farm water. Can. J. Microbiol. 37, 618-623. doi: 10.1139/m91-105

Eriksson, S., Hurme, R., and Rhen, M. (2002). Low-temperature sensors in bacteria. Philos. Trans. R. Soc. Lond. B 357, 887-893. doi: 10.1098/rstb.200 2.1077

Falconi, M., Colonna, B., Prosseda, G., Micheli, G., and Gualezi, C. O. (1998). Thermoregulation of Shigella and Escherichia coli EIEC pathogenicity: a temperature-dependent structural transition of DNA modulates accessibility of virF promoter to transcriptional repressor H-NS. EMBO J. 17, 7033-7043. doi: 10.1093/emboj/17.23.7033

Fass, E., and Groisman, E. A. (2009). Control of Salmonella pathogenicity island-2 gene expression. Curr. Opin. Microbiol. 12, 199-204. doi: 10.1016/j.mib.2009.01.004

Fernandez, L., Lopez, J. R., Secades, P., Menendez, A., Marquez, I., and Guijarro, J. A. (2003). In vitro and in vivo studies of the Yrp1 protease from Yersinia ruckeri and its role in protective immunity against enteric red mouth disease of salmonids. Appl. Environ. Microbiol. 69, 7328-7335. doi: 10.1128/AEM.69.12.7328-7335.2003

Fernandez, L., Marquez, I., and Guijarro, J. A. (2004). Identification of specific in vivo-induced (ivi) genes in Yersinia ruckeri and analysis of ruckerbactin, a catecholate siderophore iron acquisition system. Appl. Environ. Microbiol. 70, 5199-5207. doi: 10.1128/AEM.70.9.5199-5207.2004

Fernandez, L., Méndez, J., and Guijarro, J. A. (2007a). Molecular virulence mechanisms of the fish pathogen Yersinia ruckeri. Vet. Microbiol. 125, 1-10. doi: 10.1016/j.vetmic.2007.06.013

Fernandez, L., Prieto, M., and Guijarro, J. A. (2007b). The iron- and temperatureregulated haemolysin YhlA is a virulence factor of Yersinia ruckeri. Microbiology 153, 483-489. doi: 10.1099/mic.0.29284-0

Fernandez, L., Secades, P., Lopez, J. R., Marquez, I., and Guijarro, J. A. (2002). Isolation and analysis of a protease gene with an $\mathrm{ABC}$ transport system in the fish pathogen Yersinia ruckeri: insertional mutagenesis and involvement in virulence. Microbiology 148, 2233-2243.

Ferrario, C., Ricci, G., Borgo, F., Rollando, A., and Fortina, M. G. (2012). Genetic investigation within Lactococcus garvieae revealed two genomic linages. FEMS Microbiol. Lett. 332, 153-161. doi: 10.1111/j.1574-6968.2012.02591.x

Gal-Mor, O., Valdez, Y., and Finlay, B. B. (2006). The temperature-sensing protein TlpA is repressed by PhoP and dispensable for virulence of Salmonella enterica serovar Typhimurium in mice. Microbes Infect. 8, 2154-2162. doi: 10.1016/j.micinf.2006.04.015

Ginsburg, I. (2002). The role of bacteriolysis in the pathophysiology of inflammation, infection and post-infectious sequela. APMIS 110, 753-770. doi: 10.1034/j.1600-0463.2002.1101101.x

Giuliodori, A. M., Di Pietro, F., Marzi, S., Masquida, B., Wagnerm, R., Romby, P., et al. (2010). The cspA mRNA is a thermosensor that modulates translation of the cold-shock protein CspA. Mol. Cell 37, 21-33. doi: 10.1016/j.molcel.2009.11.033

Gómez, E., Pérez-Pascual, D., Fernández, L., Méndez, J., Reimundo, P., Navias, R., et al. (2012). Construction and validation of a GFP-based vector for promoter expression analysis in the fish pathogen Flavobacterium psychrophilum. Gene 479, 263-268. doi: 10.1016/j.gene.2012.01.069

Grosso-Becerra, M. V., Croda-Garcia, G., Merino, E., Servin-Gonzalez, L., MojicaEspinosa, R., and Soberon-Chavez, G. (2014). Regulation of Pseudomonas aeruginosa virulence factors by two novel RNA thermometers. Proc. Natl. Acad. Sci. U.S.A. 111, 15562-15567. doi: 10.1073/pnas.1402536111

Guisbert, E., Yura, T., Rhodius, V. A., and Gross, C. A. (2008). Convergence of molecular, modelling, and systems approaches for an understanding of the Escherichia coli heat shock response. Microbiol. Mol. Biol. Rev. 72, 545-554. doi: 10.1128/MMBR.00007-08

Han, Y., Liu, L., Fang, N., Yang, R., and Zhou, D. (2013). Regulation of pathogenicity by noncoding RNAs in bacteria. Fut. Microbiol. 8, 579-591. doi: $10.221 /$ fmb.13.20

Hansen, H., Bjelland, A. M., Ronessen, M., Robertsen, E., and Willassen, N. P. (2014). LitR is a repressor of syp genes and has a temperaturesensitive regulatory effect on biofilm formation and colony morphology in vibrio (Aliivibrio) salmonicida. Appl. Environ. Microbiol. 80, 5530-5541. doi: 10.1128/AEM.01239-1

Hansen, H., Purohit, A. A., Leiros, H. K., Johansen, J. A., Kellermann, S. J., Bjelland, A. M., et al. (2015). The autoinducer synthases LuxI and AinS are responsible for temperature-dependent AHL production in the fish pathogen Aliivibrio salmonicida. BMC Microbiol. 15:69. doi: 10.1186/s12866-015-0402-z

Herbst, K., Bujara, M., Heroven, A. K., Opitz, W., Weichert, M., Zimmermann, A., et al. (2009). Intrinsic thermal sensing controls proteolysis of Yersinia virulence regulator RovA. PLoS Pathog. 5:e1000435. doi: 10.1371/journal.ppat.1000435

Hesami, S., Metcalf, D. S., Lumsden, J. S., and MacInnes, J. I. (2011). Identification of cold-temperature-regulated genes in Flavobacterium psychrophilum. Appl. Environ. Microbiol. 77, 1593-1600. doi: 10.1128/AEM.01717-10

Heung, L. J., and Del Poeta, M. (2005). Unlocking the DEAD-box: a key to cryotococcal virulence? J. Clin. Invest. 115, 593-595. doi: 10.1172/JCI200 524508

Holm, K. O., Strom, E., Stensvaag, K., Raa, J., and Jorgensen, T. O. (1985). Characteristics of a Vibrio sp. asociated with the "Htra disease" of Atlantic salmon in Norwegian fish farm. Fish Pathol. 20, 125-129. doi: $10.3147 /$ jsfp. 20.125

Hoy, B., Brandstetter, H., and Wessler, S. (2012). The stability and activity of recombinant Helicobacter pylori HtrA under stress conditions. J. Basic Microbiol. 53, 402-409. doi: 10.1002/jobm.201200074

Hurme, R., and Rhen, M. (1998). Temperature sensing in bacteria gene regulationwhat it all boils down to. Mol. Microbiol. 30, 1-6. doi: 10.1046/j.13652958.1998.01049.x

Jimenez, N., Canals, R., Saló, M. T., Vilches, S., Merino, S., and Tomás, J. M. (2008). The Aeromonas hydrophila wb* w3 $^{*}$ gene cluster: genetics and temperature regulation. J. Bacteriol. 190, 4198-4209. doi: 10.1128/JB.00153-08

Jin, S., Song, Y. N., Deng, W. Y., Gordon, M. P., and Nester, E. W. (1993). The regulatory VirA protein of Agrobacterium tumefaciens does not function at elevated temperatures. J. Bacteriol. 175, 6830-6835.

Johansson, J., and Cossart, P. (2003). RNA-mediated control of virulence gene expression in bacterial pathogens. Trends Microbiol. 11, 280-285. doi: $10.1016 /$ S0966-842X(03)00118-5 
Jones, A. L., Needham, R. H., and Rubens, C. E. (2003). Rhe Delta subunit of RNA polymerase is required for virulence of Straptococcus agalactiae. Infect. Immun. 71, 4011-4017. doi: 10.1128/IAI.71.7.4011-4017.2003

Kamp, H. D., and Higgins, D. E. (2011). A protein Thermometer controls temperature-dependent transcription of flagellar motility genes in Listeria monocytogenes. PLoS Pathog. 7:e1002153. doi: 10.1371/journal.ppat.1002153

Konkel, M. E., and Tilly, K. (2000). Temperature-regulated expression of bacterial virulence genes. Microbes Infect. 2, 157-166. doi: 10.1016/S12864579(00)00272-0

Kortmann, J., and Narberhaus, F. (2012). Bacterial RNA thermomethers: molecular zippers and switches. Nat. Rev. Microbiol. 10, 255-265. doi: 10.1038/nrmicro2730

Lim, J., Thomas, T., and Cavicchioli, R. (2000). Low temperatures regulated DEADbox RNA helicase from the Antartic archacon Methanococcoides burtonii. J. Mol. Biol. 297, 553-567. doi: 10.1006/jmbi.2000.3585

Lv, Y., Yin, K., Shao, S., Wang, Q., and Zhang, Y. (2013). Comparative proteomic analysis reveals new components of the PhoP regulon and highlights a role for PhoP in the regulation of genes encoding the F1F0 ATP synthase in Edwardsiella tarda. Microbiology 159, 1340-1351. doi: 10.1099/mic.0.066803-0

Lybecker, M. C., and Samuels, D. S. (2007). Temperature-induced regulation of RpoS by small RNA in Borrelia burgdorferi. Mol. Microbiol. 64, 1075-1089. doi: $10.1111 /$ j.1365-2958.2007.05716.x

Marceau, M. (2005). Transcriptional regulation in Yersinia: an update. Curr. Issues Mol. Biol. 7, 151-178.

McCullen, C. A., Benhammou, J. N., Majdalani, N., and Gottesman, S. (2010). Mechanism of positive regulation by DsrA and RprA small noncoding RNAs: pairing increase translation and protects rpoS mRNA from degradation. J. Bacteriol. 192, 5559-5571. doi: 10.1128/JB.00464-10

Melchers, L. S., Regensburg-Tuink, T. J., Boutret, R. B., Sedee, N. J., Schilperoort, R. A., and Hooykaas, P. J. (1989). Membrane topology and fuctional analysis of the sensor protein VirA of Agrobacterium tumefaciens. EMBO J. 8, 1919-1925.

Méndez, J., and Guijarro, J. A. (2013). In vivo monitoring of Yersinia ruckeri in fish tissues: progression and virulence gene expression. Environ. Microbiol. Rep. 5, 179-185. doi: 10.1111/1758-2229.12030

Méndez, J., Fernández, L., Menéndez, A., Reimundo, P., Pérez-Pascual, D., Navais, R., et al. (2009). A chromosomally located traHIJKCLMN operon encoding a putative type IV secretion system is involved in the virulence of Yersinia ruckeri. Appl. Environ. Microbiol. 75, 937-945. doi: 10.1128/AEM.01377-08

Merino, S., Camprubi, S., and Tomás, H. J. M. (1992). Effect of growth temperature on outer membrane components and virulence of Aeromonas hydrophila strains of serotype O:34. Infect. Immun. 60, 4343-4349.

Mohanty, B. R., and Sahoo, P. K. (2007). Edwardsiellosis in fish: a brief review. J. Biosci. 32, 1331-1344. doi: 10.1007/s12038-007-0143-8

O'Neil, H. S., and Marquis, H. (2006). Listeria monocytogenes flagella are used for motility, not as adhesins, to increase host cell invasion. Infect. Immun. 74, 6675-6681. doi: 10.1128/IAI.00886-06

Osiri, M., Tantawichien, T., and Deesomchock, U. (1997). Edwardsiella tarda bacteremia and septic arthritis in a patient with diabetes mellitus. Southcast Asian J. Trop. Med. Public Health 28, 669-672.

Ostland, V. E., Byrne, P. J., Hoover, G., and Fergurson, H. W. (2000). Necrotic myosis of rainbow trout Oncorhynchus mykiss (Walbaum): proteolytic characterization of a crude extracellular preparation from Flavobacterium psychrophilum. J. Fish Dis. 23, 329-336. doi: 10.1046/j.1365-2761.2000. 00251.x

Palmer, D. A., and Bender, C. L. (1993). Effects of environmental and nutritional factors on production of the polypeptide phytotoxin coronatine by Pseudomonas syringae pv. Glycinea. Appl. Environ. Microbiol. 59, 1619-1626.

Pérez-Pascual, D., Gomez, E., Álvarez, B., Méndez, J., Reimundo, P., Navais, R., et al. (2011). Comparative analysis and mutation effects of fpp2-fpp1 tandem genes encoding proteolytic extracellular enzymes of Flavobacterium psychrophilum. Microbiology 157, 1196-1204. doi: 10.1099/mic.0.046938-0

Plumb, J. A. (1993). "Edwardsiella septicamia," in Bacterial Diseases of Fish, eds V. Inglis, R. J. Roberts, and N. R. Bromage (Cambridge: Cambridge University Press), 61-79.

Rapoila, F., and Gottesman, S. (2001). Signal transduction cascade for regulation of RpoS: temperature regulation of DsrA. J. Bacteriol. 183, 4012-4023. doi: 10.1128/JB.183.13.4012-4023.2001
Rapoila, F., Majdalani, N., and Gottesman, S. (2003). Small non-coding RNAs, coordinators of adaptation processes in Escherichia coli: the RpoS paradigm. Mol. Microbiol. 48, 855-865. doi: 10.1046/j.1365-2958.2003.03454.x

Rattanama, P., Thompson, J. R., Kongkerd, N., Srinitiwarawong, K., and Vuddhakul, V. (2012). Sigma E controls hemolytic activity and virulence in a shrimp pathogenci Vibrio harveyi. PLoS ONE 7:e32523. doi: 10.1371/journal pone. 0032523

Reimundo, P., Rivas, A. J., Osorio, C. R., Mendez, J., Pérez-Pascual, D., Navais, R., et al. (2011). Application of suppressive subtractive hybridization to the identification of genetic differences between two Lactococcus garvieae strains showing distinct virulence degree for rainbow trout and mouse. Microbiology 150, 2106-2119. doi: 10.1099/mic.0.047969-0

Romalde, J. L., Dieguez, A. L., Lasa, A., and Balboa, S. (2014). New Vibrio species associated to molluscan microbiota: a review. Front. Microbiol. 4:413. doi: 10.3389/fmicb.2013.00413

Rouf, M. A., and Rigney, M. M. (1971). Growth temperatures and temperature characteristics of Aeromonas. Appl. Environ. Microbiol. 22, 503-506.

Russo, G., Lannetta, M., D’Abramo, A., Mascelino, M. T., Pantosti, A., Erario, L., et al. (2012). Lactococcus garvieae endocarditis in a patient with colonic diverticulosis: first case report on Italy and review of the literature. New Microbiol. 35, 495-501.

Scherer, S., and Neuhaus, K. (2006). "Life at low temperatures," in The Prokaryotes, Vol. 2, eds M. Dworkin, S. Falkow, E. Rosenberg, K.-H. Schleifer, and E. Stackebrandt (New York, NY: Springer-Verlag), 210-261.

Schmid, S. R., and Linder, P. (1992). D-E-A-D- protein family of putative RNA helicases. Mol. Microbiol. 6, 283-292. doi: 10.1111/j.1365-2958.1992.tb01470.x

Schumann, W. (2012). Thermosensor systems in eubacteria. Adv. Exp. Med. Biol. 739, 1-16. doi: 10.1007/978-1-4614-1704-0_1

Secades, P., Alvarez, B., and Guijarro, J. A. (2001). Purification and characterization of a psychrophilic, calcium-induced, growth-phase-dependent metalloprotease from the fish pathogen Flavobacterium psychrophilum. Appl. Environ. Microbiol. 67, 2436-2444. doi: 10.1128/AEM.67.6.2436-2444.2001

Seepersaud, R., Needham, R. H., Kim, C. S., and Jones, A. L. (2006). Abundance of the delta subunit of RNA polymerase in linked to the virulence of Streptococcus agalactiae. J. Bacteriol. 188, 2096-2105. doi: 10.1128/JB.188.6.2096.210 5.2006

Shamovsky, I., and Nudler, E. (2008). New insights into the mechanisms of heat shock response activation. Cell Mol. Life Sci. 65, 855-861. doi: 10.1007/s00018008-7458-y

Sharma-Kuinkel, B. K., Mann, E. E., Ahn, J.-S., Kuechenmeister, L. J., Dunman, P. M., and Bayles, K. W. (2009). The Staphylococcus aureus LytSR twocomponent regulatory system affects biofilm formation. J. Bacteriol. 191, 4767-4775. doi: 10.1128/JB.00348-09

Shen, A., and Higgins, D. E. (2006). The MogR transcriptional repressor regulates nonhierachal expression of flagellar motility genes and virulence in Listeria monocytogenes. PLoS Pathog. 2:e30. doi: 10.1371/journal.ppat.0020030

Shivaji, S., Jogadhenu, S., and Prakash, S. (2010). How bacteria sense and respond to low temperature? Arch. Microbiol. 192, 85-95. doi: 10.1007/s00203-009-0539-y

Slaven, E. M., Lopez, F. A., Hart, S. M., and Sanders, C. V. (2001). Myoncrosis caused by Edwardsiella tarda: a case report and case series of extraintestinal E. tarda infections. Clin. Infect. Dis. 32, 1430-1433. doi: 10.1086/320152

Smirnova, A., Hongqiao, L., Weingart, H., Aufhammer, S., Burse, A., Finis, K., et al. (2001). Thermoregulated expression of virulence factors in plant-associated bacteria. Arch. Microbiol. 176, 393-399. doi: 10.1007/s002030100344

Srinivasa Rao, P. S., Lim, T. M., and Leung, K. Y. (2003). Functional genomic approach to the identification of virulence genes involved in Edwardsiella tarda pathogenesis. Infect. Immun. 71, 1343-1351. doi: 10.1128/IAI.71.3.13431351.2003

Srinivasa Rao, P. S., Yamada, Y., Tan, Y. P., and Leung, K. Y. (2004). Use of proteomics to identify novel virulence determinants that are requires for Edwardsiella tarda pathogenesis. Mol. Microbiol. 53, 573-586. doi: 10.1111/j.1365-2958.2004.04123.x

Starliper, C. E. (2011). Bacterial coldwater disease of fishes caused by Flavobacterium psychrophilum. J. Adv. Res. 2, 97-108. doi: 10.1016/j.jare.2010.04.001

Steinmann, R., and Dersch, P. (2013). Thermosensing to adjust bacterial virulence in a fluctuating enviroment. Future Microbiol. 8, 85-105. doi: 10.2217/fmb.12.129 
Thune, R. L., Stanley, L. A., and Cooper, K. (1993). Pathogenesis of gram-negative bacterial infections in warm water fish. Ann. Rev. Fish. Dis. 3, 37-68. doi: 10.1016/0959-8030(93)90028-A

Ullrich, M., Penaloza-Vazquez, A., Bailey, A. M., and Bender, C. L. (1995). A modified two-component regulatory system is involved in temperaturedependent biosynthesis of the Pesudomonas syringae phytotoxin coronatine. J. Bacteriol. 177, 6160-6169.

Vendrell, D., Balcazar, J. L., Ruiz-Zarzuela, I., de Blas, I., Girones, O., and Múzquiz, J. L. (2006). Lactococcus garvieae in fish: a review. Comp. Immunol. Microbiol. Infect. Dis. 29, 177-198. doi: 10.1016/j.cimid2006.06.003

Wang, X., Wang, Q. Y., XiaO, J. F., Liu, Q., Wu, H. Z., Xu, L., et al. (2009). Edwardsiella tarda T6SS component evpP is regulated by esrB and iron, and plays essential roles in the invasion of fish. Fish Shellfish Inmunol. 27, 469-477. doi: 10.1016/j.fsi.2009.06.013

Ware, D., Jiang, Y., and Swiatio, L. W. (2006). Involvement of potD in Streptococcus pneumoniae polyamine transport and pathogenesis. Infect. Immun. 74, 352 361. doi: 10.1128/IAI.74.1.352-361.2006

Weber, G. C., Kortmann, J., Narberhaus, F., and Klose, K. E. (2014). RNA thermometer controls temperature-dependent virulence factor expression in Vibrio cholerae. Proc. Natl. Acad. Sci. U.S.A. 111, 14241-14246. doi: 10.1073/pnas.141570111

White-Ziegler, C. A., and Davis, T. R. (2009). Genome-wide identification of H-NScontrolled, temperature-regulated genes in Escherichia coli K-12. J. Bacteriol. 191, 1106-1110. doi: 10.1128/JB.00599-08

Yamanaka, K., Mitta, M., and Inouye, M. (1999). Mutation analysis of the 5 'untraslated region of the cold shock cspA mRNA of Escherichia coli. J. Bacteriol. 181, 6284-6292.
Yang, C. H., and Wang, C. K. (1999). Edwardsiella tarda bacteraemia complicated by acute pancreatitis and pyomyoma. J. Infect. 38, 124-126. doi: 10.1016/S01634453(99)90081-6

Yu, H. B., Kaur, R., Lim, S., Wang, X. H., and Leung, K. Y. (2007). Characterization of extracellular proteins produced by Aeromonas hydrophila AH-1. Proteomics 7, 436-449. doi: 10.1002/pmic.200 600396

Zheng, J., Tung, S. L., and Leung, K. Y. (2005). Regulation of a type III and putative secretion system in Edwardsiella tarda by EsrC is under the control of a two-component system EsrA-EsrB. Infect. Immun. 73, 4127-4137. doi: 10.1128/IAI.73.7.4127-4137.2005

Zhou, Z.-J., Sun, B.-G., and Sun, L. (2015). Edwardsiella tarda Sip1: a seruminduced zinc metalloprotease that is essential to serum resistance and host infection. Vet. Microbiol. 177, 332-340. doi: 10/1016/j.vetmic.2015. 03.030

Conflict of Interest Statement: The authors declare that the research was conducted in the absence of any commercial or financial relationships that could be construed as a potential conflict of interest.

Copyright (c) 2015 Guijarro, Cascales, García-Torrico, García-Domínguez and Méndez. This is an open-access article distributed under the terms of the Creative Commons Attribution License (CC BY). The use, distribution or reproduction in other forums is permitted, provided the original author(s) or licensor are credited and that the original publication in this journal is cited, in accordance with accepted academic practice. No use, distribution or reproduction is permitted which does not comply with these terms. 